\title{
Internet Representations of Voluntourism Fail to Effectively Integrate Tourism and Volunteering
}

\author{
Voluntourism as a form of philanthropic tourism has become an increasingly \\ popular research topic but there is a paucity of literature on the complex interplay \\ between voluntourism and the internet. Specifically, there is sparse evidence on \\ how the internet mediates ideas and representations of voluntourism. Building on \\ prior research in the information search field, we examine the online \\ representation of voluntourism in South Africa - a popular destination for \\ voluntourists. Querying a popular search engine using a combination of \\ keywords, we retrieved 600 web pages, which were stored and analysed using a \\ predefined codebook. We employ social representation theory as an analytical \\ tool for interpreting the retrieved search engine content. Results indicate three \\ distinct clusters: the first is related to the volunteering experience itself, the \\ second focuses on the touristic experience, and the third encompasses the \\ voluntourism journey as a whole. These clusters reveal a misleading \\ representation of voluntourism in the online space: voluntourism is \\ predominantly represented as a cultural experience, with a strong presence of its \\ key components (i.e. tourism and volunteering) and only a weak holistic view \\ that integrates the two. In light of these findings, we conclude that internet \\ representations of voluntourism do not integrate tourism and volunteering \\ impactfully, which counteracts effective marketing of the industry. These results \\ help voluntourist organisations in South Africa and internationally to improve \\ their online targeting mechanisms to promote their services more accurately.
}

Keywords: volunteering; tourism; voluntourism, internet; South Africa; social representation theory; information search; online domain.

\section{Introduction}

Volunteer tourism (or, voluntourism) is a form of altruistic tourism in which travel is combined with voluntary service. Voluntourism was historically discussed as being a complex, ambiguous field (Lyons \& Wearing, 2008). Callanan and Thomas (2005) described voluntourism as an eclectic tourism product of a multidimensional nature. The field has seen growing academic interest in recent years (see Hammersley, 2014; Taplin, Dredge, \& Scherrer, 2014) with some authors discussing positive and enthusiastic positions (Lupoli, Morse, Bailey, \& Schelhas, 2014) and some other adopting a more critical position (e.g. Guttentag, 2009; Lyons \& Wearing, 2012). 
Voluntourism can be understood as an alternative form of tourism (Lyons \& Wearing, 2008). It typically involves 'developmental' activities in under-resourced, poor and marginalised settings, in the spheres of health, education, and the environment, among others (Wearing, 2001). For the purpose of this paper, we use a definition proposed by Hammersley (2014), adapted from the work of McGehee and Santos (2005). According to this definition, voluntourism can be understood as "the use of discretionary time and income to travel out the sphere of regular activity and participate in a period of engagement with local, national or world community" (2014:857). Voluntourism is considered both personally rewarding for the individual voluntourist (Conran, 2011), as well as beneficial for the host community or group (Lupoli, Morse, Bailey, \& Schelhas, 2014). But while it is seen to promote reciprocal relationships between hosts and guests (McIntosh \& Zahra, 2007), voluntourism can also be a vehicle for the unintended exploitation of local groups, as they succumb to economic and cultural pressures to 'perform for' and host foreign (typically Western) voluntourists (Pastran, 2014). Nonetheless, voluntourism can be considered as an ideologically different mode of tourism that is considered more sustainable and locally beneficial than consumer-driven and mass-market tourism (Stoddart \& Rogerson, 2004).

There is a growing body of literature that focuses mainly on two issues: (i) academics are debating the ambitions and motivations of volunteer-tourists (Daldeniz \& Hampton, 2010) and the transformative learning experience sought by voluntourists (Knollenberg, McGehee, Boley, \& Clemmons, 2014); (ii) the impact on hosting communities (Wang \& Pfister, 2008) or power dynamics in such communities (McGehee \& Andereck, 2009). However, what remains unclear is the nature of the relationship between voluntourism and digital technologies (McGehee, 2014); or in other words, how voluntourist services are accessed, negotiated, and experienced in or through the online domain (Van Zyl, Inversini, \& Rega, 2015). In the recent Special Issue of the Journal of Sustainable Tourism, McGehee (2014) emphasises the importance of digital technology and the internet in respect of voluntourism and calls for more research to be conducted in the field. Indeed, little or no research to date has examined how the internet mediates voluntourism experiences, and particularly how voluntourism is represented online (Van Zyl et al., 2015). This article responds to the paucity of technology-focused research in the voluntourism field. Our intention here is to stimulate debate on the issue. Indeed, the internet has long played a significant role in the global tourism industry (Buhalis, 2003). This is both in terms of accessing and mediating touristic experiences (Buhalis \& Law, 2008) which in the voluntourism field are socially motivated (Wearing \& McGehee, 2013), and in supporting sustainable development in local communities (Nor \& Muhlberger, 2011).

Therefore, the role of the internet in mediating voluntourism as both a subset of tourism and as a tool to foster socio-economic development must be explored in more depth. In light of this, we designed a study to explore the internet-mediated social representation of voluntourism. In other words, this research will investigate shared perceptions about voluntourism as they appear in the online domain. To enable such 
understanding, this work draws from two streams of research: Social Representation Theory and Information Search. Social representation theory (Moscovici, 1961) claims that socio-psychological phenomena and processes can only be properly understood if they are seen as "being embedded in historical, cultural and macro social conditions" (Wagner et al., 1999). To leverage this theory within the area of tourism, we draw from leading social representation theorists and social psychologists, notably Moscovici (1961), Howarth (2006; 2011), and Wagner and colleagues (1999). Social representation theory, is particularly relevant when a new phenomenon is on the rise: the theory suggests people anchor their views of the new phenomenon to existing knowledge, understanding or common sense (Moscovici, 2000).

Socially shared meaning is here studied within the so-called 'Online Tourism Domain' (Xiang \& Gretzel, 2010; Xiang, Wöber, \& Fesenmaier, 2008). Xiang and colleagues (2008 and 2010) have in fact investigated the information landscape accessible through search engines about a given tourism destination. Aside from depicting the nature and composition of this domain, such studies discuss search engines as the predominant 'gateways' to information on the internet (Jang, 2004). Travellers use search engines in all phases of tourism goods consumption (Gretzel, Fesenmaier, \& O'Leary, 2006) to receive information, to transact, and to get recommendations (Pan \& Fesenmaier, 2006) from tourism companies and other travellers (Xiang \& Gretzel, 2010). Therefore, in order to access representations of voluntourism, search engines are here regarded as the entry point in respect of collecting relevant content to be processed and analysed with social representation theory. For the empirical purposes of this study, voluntourism websites were selected as our unit of analysis. The internet as a vast and complex collation of websites is often the first point of contact for prospective voluntourists. It is within this structure that we frame our empirical research. The country (or, online domain) of South Africa is selected as empirical setting due to being a globally popular tourist and volunteer-tourist destination (Stoddart \& Rogerson, 2004).

In what follows, we provide some context to the notion of voluntourism. We firstly discuss the phenomenon in terms of development and sustainability. Thereafter, we give an overview of voluntourism in South Africa. This is followed by a review of our theoretical framework and research design. Following this, we present and discuss our empirical results, and note the implications for future research.

\section{Literature review}

\section{Voluntourism and the politics of sustainability}

Voluntourism has several definitions but generally refers to the combination of volunteer work and tourism. It typically entails participation in short-term, youthfocused, volunteer abroad programmes (Dykhuis, 2010). Other definitions state that voluntourism is a form of tourism based on international, inter-social and intercultural 
cooperation to maximise the common good in supporting sustainable development (Corti, Marola, \& Castro, 2010). Volunteer-tourists generally offer their time, knowledge, skills or financial resources to benefit other people or causes, while coupling this with traditional elements of travel in the chosen destination (Wearing, 2001). Voluntourism is today a significant, popular and expanding activity in the global tourism industry: it is promoted as an alternative to mass tourism, often criticised for its failure to deliver real benefits to hosting environments and communities (Sin, 2010). Voluntourism is therefore regarded as a catalyst for developing the potential of tourism destinations (Hawkins, Lamoureux, \& Clemmons, 2005), and as a form of ethical travel that is more benign to local communities and the natural environment ( $\operatorname{Sin}, 2009$ ).

In this way, the nature and practice of voluntourism also bring to bear questions of local sustainability (Kennedy \& Dornan, 2009) and exploitative development (Pastran, 2014). Voluntourist destinations are often sought in the Global South: countries with typically low levels of human development, widespread poverty and inequality, and with resource scarcity (Guttentag, 2011). Volunteer-tourists who travel to these destinations normally have what Corti et al. (2010:223) refer to as "high purchasing power" and are therefore in positions of influence. This is a power imbalance that can reinforce the contentious role of tourism as a "redistributor of wealth" and transmitter of so-called "inclusive values" in under-developed contexts (Corti et al., 2010: 223). These tensions can be both subtle and overt, and undermine the sustainable potential of voluntourism in local contexts (Kass, 2013). This is in some respects connected to classic imperial approaches to development (Nash, 1989), in which segregated ("Third World") societies are mapped and produced, and placed under conditions in which they seek the enlightenment of Western modernity and economy (Escobar, 2011). Such forms of 'colonial humanitarianism' are often entrenched in the modern-day practice of international voluntourism (Clost, 2011). Moreover, while volunteer-tourists can play a positive role in the upliftment of local destinations (Conran, 2011), initiatives are often short-lived or volunteer visits are temporary (Alexander, 2012). This can result in a high turnover of volunteers and a continual reintegration in respect of the organisations and initiatives concerned. Furthermore, voluntourists are often driven by intrinsic and personal motivations that do not always fit the expectations of hosting organisations or groups (Daldeniz \& Hampton, 2010). These are likely coupled with the incentive to travel beyond the immediate place of volunteering (Holmes, Smith, Lockstone-Binney, \& Baum, 2010). This aspect becomes an important consideration for local hosts. Voluntourist packages must thus balance immersive experiences (as a form of cultural exchange), philanthropy (as a form of sustainable local development), and tourism (as a form of commercial travel) (Corti et al., 2011).

These aspects point to the role of 'sustainable marketisation' (Bianchi, 2004): presenting and promoting lucrative experiences to prospective volunteer-tourists in a manner that is conducive to local needs and expectations. The voluntourism sector has indeed seen rapid expansion and commercialisation (Butcher, 2011), although with 
lesser consideration for the plural realities in marginalised and often peripheral communities (Raymond, 2011). In light of this, there have been increasing calls for improving the viability of the industry, both in terms of attracting prospective touristvolunteers, and maintaining sustainable practices in local settings (Mostafanezhad \& Kontogeorgopoulos, 2014), thereby challenging the "romantic views of poverty" (Butcher, 2011:75) that the industry seems to foster. A recent study by Everingham (2016) tried to move beyond the notions of culture, identity and power relations in voluntourism and framed the phenomenon within the constructs of embodiment, affect and emotion to provide more nuanced insights into the ambiguities of volunteer experiences.

A growing body of literature adopts a newly critical approach toward the study of voluntourism and questions (i) the idealistic depiction of the sector in many existing studies (Guttentag, 2009), (ii) the real impact on hosting communities (Raymond, 2011), and (iii) the over-marketisation of the industry (Lyons \& Wearing, 2008). Additionally, as Lyons and Wearing (2012) point out, what motivates volunteer travellers is not always primarily altruistic. Voluntourists are also motivated by factors such as the opportunity to travel, to develop social connections, or to develop skills that will help with their individual careers. However, Stebbins (2009) suggests that selfservice does not come at the expense of altruism; that they are somehow related and not mutually exclusive. While studying the transformative power of voluntourism as a learning experience, Knollenberg and colleagues (2014) discovered other motivations beyond altruism and self-development in the three clusters considered for their analysis - volunteers, voluntourists and tourists. These included the desire to experience different cultures, build relationships with family, and to escape from daily life, all assuming a greater role for participating in such an experience.

\section{Voluntourism in South Africa}

South Africa is a popular destination for both tourists and volunteer-tourists (Alexander, 2012; Nelson, 2010). In his analysis of volunteer tourism destinations, Keese (2011) placed South Africa (and particularly Cape Town) at the second place as most popular voluntourism destination, second only to Oaxaca (Mexico) and first in terms of English speaking destinations. There is an abundance of responsible tourism initiatives throughout the country, ranging from environmental activities, to health promotion, to sport and wellbeing programmes (Spenceley \& Goodwin, 2007). The local industry is well regulated, sanctioned by the Cape Town Declaration on Responsible Tourism in 2002. This historic declaration recognises tourism's role in addressing the "global challenge" of social and economic inequalities and poverty (Cape Town Declaration, 2002). Several guiding principles were proposed in this declaration, including the generation of greater economic benefits for local people, providing more meaningful experiences for volunteers and tourists, and promoting a greater understanding of diversity and local culture (Alexander, 2012). 
A decade later, the South African Department of Tourism approved the National Minimum Standard for Responsible Tourism (SANS 1162, 2011). This was created to establish a common understanding of responsible tourism, and to be the baseline standard for tourism businesses in the country (Van Zyl et al., 2015). The Standard underlines that tourism should be a mechanism toward a more inclusive economy, but should also provide access to local communities and support local development initiatives. By developing a single set of standards to be applied throughout South Africa, the NMRST has "harmonised the different sets of criteria that were used for certifying the sustainability of tourism businesses" (SANS 1162, 2011). This bodes well for the voluntourist sector in the country, through providing more sustainable travel experiences and business opportunities for local enterprises.

However, despite the strong policy framework for sustainable tourism in South Africa, there is a paucity of research on the practices and experiences of volunteertourists in the country (Nelson, 2010). The lack of research is most evident in the study of volunteer-touristic activities in local communities, but also in understanding how voluntourist experiences are accessed, (re)presented, and negotiated by prospective volunteers in a South African context (Van Zyl et al., 2015). Especially in terms of the online domain, voluntourism is sparsely researched, with some arguing that more substantive research is needed (see (McGehee, 2014).

\section{Theoretical landscape}

The following passages highlight the theoretical perspectives that underpin this study. The present study draws from social representation theory and information search literature.

\section{Social representation theory}

Volunteer-tourism is enacted through differing individual motivations (Tiessen, 2012): each individual attaches different personal meanings to the actual volunteer-tourism experience (Conran, 2011). Individual motivations are collectively negotiated, both virtually and physically, giving rise to a plethora of social representations. In this paper, we argue that social representations of voluntourism can be elicited from content published online (Rosa, 2012) by different information providers (for example, voluntourism associations, social media, and destination websites). To do so, we apply social representation theory (Moscovici, 1961) to the study of online content about volunteer tourism in a South African context. A number of researchers have used social representation theory to analyse attitudes towards, and responses to, tourism development (Andriotis \& Vaughan, 2003; Fredline, Jago, \& Derry, 2003; Yuksel, Bramwell, \& Yuksel, 1999). Recently, this theory has been applied more broadly (Dickinson \& Dickinson, 2006; Dickinson \& Robbins, 2008; Dickinson, Robbins, \& Fletcher, 2009) to the study of transport, planning and governance in tourism. 
Social representation theory is a "social psychological framework of concepts and ideas used to study psycho-social phenomena in modern societies" (Wagner et al., 1999), pioneered by Serge Moscovici (1961). Moscovici grounded his theoretical perspective on Durkheim's (1898) sociological notion of collective representations, that considers the individual mind as "a microcosm of the collective conscience of the society, reflecting forms and contents of the social world" (Parker, 1987). Moscovici coined the term social representations (SRs) to take into consideration the dynamism and fluidity of these phenomena, which can be detected in language and everyday communication (Farr, 1996; Fraser, 1994). Social representations are thus defined as the collective elaboration "of a social object by the community for the purpose of behaving and communicating" through two main mechanisms, anchoring and objectification (Moscovici, 1961:251).

Rather than being cognitive products of individuals' minds, representations are shaped in social interaction (Billig, 1996; Byford, 2002), through the process of anchoring these new elements in pre-existing categories of common sense (Moscovici, 1961, 2000). The aim of such a process is to make "familiar" the unfamiliar, allowing social actors to classify and label the new object according to stable and shared categories of concepts and images (Moscovici, 1984). Social representations are both the process and the product of social construction and negotiation. As such, they are "embedded in historical, cultural and macro social conditions" (Wagner et al., 1999).

\section{Online information search}

The internet can be regarded as a complex and interrelated collection of webpages (Baggio, Corigliano, \& Tallinucci, 2007), forming a virtual ecosystem (Baggio \& Sainaghi, 2011). Locating relevant information within this vast network is a critical and challenging task (Hecht, Teevan, Morris, \& Liebling, 2012). To this end, search engines have been the standard mechanism to provide needed information to users (Cilibrasi \& Vitanyi, 2007). Information search also forms an integral part of the tourism field, given the need to locate correct and relevant travel information (Xiang et al., 2008).

Search engines are the preferred gateway for online information search and they shape the way users perceive the available information (Wöber, 2006). A study by Xiang et al. (2008) defined the so-called Online Tourism Domain as the collection of webpages that are relevant for a given tourism query through search engines. The Online Tourism Domain is populated by different webpages, which deal with destinations' content (i.e. circa 300 pages around a given destination), and consist of a given number of domains (i.e. most search engine results are domain duplicates) with a visibility ratio (i.e. the actual accessible webpages) of $0.032 \%$ of the total indexed pages (Xiang et al., 2008).

Xiang and Gretzel (2010) found that the Online Tourism Domain is also populated by social media websites, which have gained considerable popularity within 
search result pages. While traditional websites tend to portray a neutral or positive image (e.g. of the destination - Inversini, Cantoni, \& Buhalis, 2009), social media incorporate user-generated (subjective) content. This is archived or shared online for easy access by other impressionable consumers (Blackshaw, 2006). Social media is particularly relevant for a sector like tourism, where the decision-making process is also based on the experiences of others (Gretzel \& Yoo, 2008; Pan \& Fesenmaier, 2006) or on the so-called eWord of Mouth (Litvin, Goldsmith, \& Pan, 2008).

\section{Research design}

A set of web results was collected from the popular search engine Google.com, drawing from existing literature about information search (Pan \& Fesenmaier, 2006; Xiang \& Gretzel, 2010; Xiang et al., 2008). Search engine results were firstly categorised according to manual content analysis (Inversini et al., 2009). Following this, the content of each webpage was stored for subsequent analysis by means of the software, T-Lab (ver. 5.1 - Lancia, 2012, p. 2). This approach allowed us to explore the representation of voluntourism in the textual corpus, as co-constructed and shared online by voluntourists and voluntourism organisations.

Therefore, our research design addresses two main goals:

- To investigate the meanings related to voluntourism as they are generated online;

- To map different social representations of voluntourism. This is to be grouped according to (i) website type (traditional or social media), (ii) website location (South Africa or international), and keyword type (activity/geographical keyword).

\section{Data collection}

In order to investigate social representation in the internet arena, we needed to carry out a series of search queries on Google.com. Google was selected as it is the leading gateway to online information (72.4\% market share in 2018 - Net Market Share, 2018). Search queries returned a series of results which were our units of analysis. Search queries reflect a diversity of user goals that can include navigational goals (looking for a specific web page), informational goals (trying to obtain a piece of information), and transactional goals (carrying out a certain action) (Jansen \& Molina, 2006). Jansen, Booth and Spink (2008) found that user queries are largely informational in nature $(81 \%)$, followed by navigational tasks $(10 \%)$ and transactional tasks $(9 \%)$. This study is based on informational queries as the predominant form of searching. Furthermore, in travel and tourism, studies indicate that traveller queries tend to be concise, typically consisting of less than four keywords (Jansen et al., 2008). Most travellers do not go beyond the results provided on the second or third page of a search engine (Inversini et al., 2009). A United States study claimed that online searchers usually focus on cities as 
the geographical delimiter instead of states or countries (Pan et al., 2007). Additionally, travellers often combine their searches for accommodation with other aspects of the trip, including dining, attractions, destinations, or transportation (Xiang et al., 2008).

Following the aforementioned criteria, we created three sets of keywords [Kn] to analyse the online domain of voluntourism. For each keyword, we stored and analysed the first 30 results (i.e. on the first three search pages - data collection was carried out in late 2014, from Google.com). The first set of keywords described the generic phenomenon of voluntourism in South Africa:

[K1] 'volunteer and tourism South Africa'

[K2] 'voluntourism South Africa'

The second set of keywords (K3-k11) was related to possible voluntourism activities in South Africa. These were clustered with reference to the United Nations Development Programme and its Human Development Report (United Nations Development Programme, 2013): Community Development, Human Rights, Health, Education, Heritage, Environment, Technology, Youth Development, Social Protection. All the aforementioned keywords were used in combination with 'volunteer and tourism' before the keyword and 'South Africa' after the keyword. 'Volunteer and tourism' were the preferred search terms to enhance the descriptive power of the online search. 'South Africa' gave a location boundary to the keywords.

The third set (K12-K20) of keywords was geographically related (capital cities of each of the nine provinces in the country): Cape Town, Mahikeng, Kimberley, Mbombela, Polokwane, Pietermaritzburg, Johannesburg, Bloemfontein and Bisho. While the city already indicated the physical location relevant to the search, 'volunteer and tourism' were again the preferred terms to enhance the descriptive power of the online search.

\section{Data analysis}

With respect to the designed queries, 600 web page addresses were collected: only the first three pages of the results listing were considered as relevant for this research (as they are considered relevant for end-users both from academia and industry - Inversini et al., 2009). Search engine results were stored and analysed by three coders (intercoder reliability: 0.87 Fleiss Kappa - Fleiss, 1971; Sim \& Wright, 2005). Coders described and classified the web pages in terms of a predesigned codebook (Riff, Lacy, \& Fico, 2014). Following this, coders stored all text on the website landing page in a separate file. Social media websites where analysed when text was present; for picture based social media only the textual comments were analysed. Descriptive classification was based on the following categories: website type (traditional or social media), detailed website type (e.g. consumer review, newspaper, destination site), website topic (tourism, volunteering, and voluntourism) and content types (e.g. informative, 
advertisement, comment/review). Additionally, coders were asked to classify the corpus of the webpages by means of three variables:

\section{[INSERT TABLE 1]}

Computer-aided content analysis was conducted on the content of the websites by means of T-Lab. This allowed us to explore the representation of voluntourism underlying the textual corpus, as co-constructed and shared online by voluntourists and voluntourism organisations. The content analysis consisted of three main phases. Firstly, a preliminary lemmatisation of the website content (536'214 words) led to a final list of 150 keywords with a minimum of 99 occurrences each. Secondly, a thematic analysis comprised application of the bisecting K-means clustering method (Lancia, 2012) and led to the segmentation of the textual corpus in elementary context units (ECUs). ECUs are statements extracted based on recurrent patterns of keywords, which have a minimum of 3 co-occurrences of words within each unit and a maximum of 10 clusters obtained. Thirdly, the text was normalised by TDF-IDF; a measure that weights the lexical units within each ECU. This procedure implies scaling row vectors to unit length (Salton, 1988). ECUs were classified by paragraph. The output obtained consists of a set of thematic clusters characterised by their relevant ECUs, lexical units (or lemmas) and a list of predefined categorical variables: the type of the website (traditional websites or social media websites), the website location (international or South Africa) and the keyword typology (general, activity, geography). Significant lexical units and variables are ranked by Chi2 value, a measure of the co-occurrence of each word within ECUs (Reinert, 1993). Interpretation of results was based mainly on lemmas whose Chi2 values are higher than 300 , as reported in the tables describing each cluster and in the text in italics.

\section{Results}

Traditional websites (87\%) dominated search results, the majority of which belonged to voluntourism organisations (27.5\%). A minority of the analysed websites belong to destination marketing organisations $(15.60 \%)$ or other tourism organisations $(9.90 \%)$. The surveyed websites tended to present topics about volunteering $(36.60 \%)$ or voluntourism (42.80\%). The topic of tourism appears only in one out of five search results. The content presented by the websites analysed was mostly informative in nature (78\%). Comment/review websites as well as image and discussion group websites represent a small proportion of the overall sample $(7.9 \%)$.

\section{Identified clusters}

Computer-aided content analysis led to the identification of three clusters, presented in the table below.

[INSERT TABLE 2] 
It is important to note the weight of the different clusters within the corpus. The first two clusters - "the volunteering experience" and "a tourism experience: what to see and what to do" - are similar in weight (37.6\% and $35.9 \%$ respectively). The third cluster, "a holistic view of voluntourism", has a lower weight within the corpus $(26.5 \%)$.

\section{Cluster 1: the volunteering experience}

Cluster 1 is structured around discourses about the actual experience as volunteers. The volunteer experience is depicted as an opportunity to spend some time abroad, doing a $j o b$, which can help and have an impact. Two kinds of volunteering experiences are outlined in this cluster. The first refers to activities related to support people in need, such as being involved in a teaching project with children:

\section{"[...] current volunteer projects include caring for disabled children and} orphans, volunteer teaching, and sports coaching."

The second type of activity relates to taking care of local wildlife animals:

"We [...] a selection of wildlife conservation projects, from working with lion cubs at a lion park with white lions, to breeding endangered cheetah, whale and dolphin."

\section{[INSERT TABLE 3]}

\section{Cluster 2: a tourism experience - what to see and what to do}

The second cluster is clearly depicted by discourses about touristic attractions and logistics information related to the leisure part of the voluntourism experience. This is a very practical cluster and mostly relates to actual places to see while in South Africa, such as Pietermaritzburg, Bloemfontein, Cape Town, Natal, and Kimberley; as well as to natural attractions, such as parks, bays, mountain, and safari, and cultural ones, such as museums.

"contact [...\} tours to help you organize your itinerary with car hire, accommodations and activities. [...]"

"[...] we offer a selection of day tours from cape town and surrounds, we offer day trips to table mountain, Cape Point, the winelands, township tours, Hermanus whale watching and many other day trips."

In the cluster, there is also a clear semantic unit belonging to the logistics and organisation of a tour, such as restaurants and accommodation possibilities, as well as technical information, such as contact details, telephone numbers, and email addresses. 
[INSERT TABLE 4]

\section{Cluster 3: a holistic view of voluntourism}

Finally, the third cluster refers to the voluntourism experience in its totality. Both the tourism and leisure component and the volunteering and development aspect of the experience are present in this cluster. Discourses related to both the components are more general than in the previous clusters. Indeed, the volunteering discourse is the one most explored: doing a voluntourism experience means to undertake an international adventure, which will have an impact on the life of voluntourists and on the life of the communities in which the volunteer will work.

As the third cluster deals with volunteering experiences, it is possible to note some other lemmas that do not strictly refer to the domain of volunteering and tourism, for example market, research and corporate. These lemmas probably refer to possible volunteering experiences in South Africa not directly related to voluntourism.

\section{[INSERT TABLE 5]}

\section{Variables and clusters}

Clusters can also be described by the predefined variables used. For example it is possible to understand the percentage of results deriving from the three different set of keywords in each cluster (Figure 1), the relevance of traditional or social media websites in each cluster (Figure 2), or the location (international or South African) of the website (Figure 3). In order to make the following figures readable, clusters have been named as follows: Volunteering (cluster 1), Tourism (cluster 2) and Voluntourism (cluster 3).

\section{Distribution of the variable "keyword" within the clusters}

The generic keywords (i.e. 'volunteer and tourism South Africa' and 'voluntourism South Africa') are more related to cluster 1 and cluster 3. That is to say they are more related with the actual volunteering experience. The same trend applies for the keywords related to possible volunteering activities (e.g. 'volunteer and tourism Community Development South Africa', 'volunteer and tourism Human Rights South Africa', 'volunteer and tourism Health South Africa', 'volunteer and tourism Education South Africa', and the like). Also, in this case, the greater representation is related with the actual possibilities of volunteering. It is when we consider geography (e.g. 'volunteer and tourism Cape Town', 'volunteer and tourism Mahikeng', 'volunteer and tourism Kimberley' etc.) that the tourism issue emerges. These keywords are actually much more related to cluster 2 , which deals with the tourism experience happening in a given place in geography that is eventually identified by the name of a city. 
The figure below summaries the spread of the variable keyword in each of the three clusters identified.

\section{[INSERT FIGURE 1]}

\section{Distribution of the variable "typology" within the clusters}

Interestingly, cluster 1 (volunteering) and cluster 3 (voluntourism) are mostly represented by traditional websites, while 'social' websites are mapped in the second cluster, related to the touristic dimension and to how-to information related to visit the country. Seemingly, social platforms are mostly used to exchange information about where to go, what to visit, and where to stay while travelling the country. They are less relevant for discussing actual volunteer-touristic experiences.

\section{[INSERT FIGURE 2]}

\section{Distribution of the variable "location" within the clusters}

The same happens if looking at the website domain: international website are more represented in cluster 1 and cluster 3, while local website, with a South African domain (e.g. .ZA), are more related to logistics information on how to travel in the country (cluster 2).

\section{[INSERT FIGURE 3]}

\section{Discussion and conclusion}

In this study, we investigated the mediated social representation of voluntourism in the internet arena. Twenty different keywords (generic, activity based and location based built within a defined process) were used to query Google.com and to retrieve 600 web pages. Landing pages were used to study the social representations of voluntourism as it transpires in the online environment with a focus on South Africa. While the collected data is not as current, the analysis still offers fresh insights into the nature of internet mediated voluntourism.

Results described the analysed corpus divided into three clusters. Cluster 1 "the core of the volunteering experience" and Cluster 2 "a tourism experience: what to see and what to do" have a similar weight (37.6\% and 35.9\% respectively), while Cluster 3 "a holistic view of voluntourism" has a lower weight within the corpus $(26.5 \%)$. This means that volunteer tourism can be better described by emphasising either one of the two aspects of the experience (the volunteering or the tourism side). A holistic, merged or integrated view of the phenomenon has yet to strongly emerge. The more the voluntourism phenomenon matures, the more the third cluster is expected to grow, offering a comprehensive representation thereof. 
Additionally, this result is in line with the work of (Knollenberg et al., 2014) who defined three segments of potential volunteer tourists' motivations in relation with transformative learning experiences: (i) volunteers, (ii) voluntourists and (iii) tourists. The clusters of possible voluntourists defined by Knollenberg and colleagues therefore correspond in the online representation of the domain, highlighting the possibility for each cluster to retrieve information in the online world following their mental models (Xiang et al., 2008) and/or their guiding motivations for choosing such an experience.

This research does not provide any evidence that the clusters represent discussions about deep motivations (Tiessen, 2012) such as experiencing different cultures, building relationships with family, and escaping from daily life (Knollenberg et al., 2014), and again no evidence of social representations related to community impact (Nelson, 2010) - although communities are mentioned in Cluster 3. Therefore, this research presents the socially constructed meaning of voluntourism as mediated by internet based search engines as perpetuating the discussion about 'the romantic view of poverty, and in the academic discussion, a strong post-development outlook' (Butcher, 2011, p. 75).

Findings also highlight how each predefined variable - keywords used to perform the queries, typology of website, and location of the website - are distributed within the clusters. The results highlighted that geography keywords are more likely to appear within Cluster 2; the cluster focused on the tourism part of the experience. This supports key findings in the tourism information search literature (Pan \& Fesenmaier, 2006), which sees tourism results to be driven largely by geographical/spatial factors. Generic and activity keywords are, on the contrary, mapped in Cluster 1, about the volunteering part of the experience, and in Cluster 3, where the two components (i.e. volunteering and tourism) come together. Again, we observe an unbalanced distribution of keywords within the clusters, with tourism related keywords not generating results within the second and third clusters.

Social media was predicted to be an important part of the search engine results (Xiang \& Gretzel, 2010). According to our findings, the online tourism domain related to voluntourism contained only $7.9 \%$ of social media results. However, it is interesting to note that social media is used mostly to discuss the tourism part of the experience (Cluster 2) rather than volunteering and voluntourism experiences. This may be related to the popularity of social media tourism websites (e.g. TripAdvisor - Gretzel \& Yoo, 2008) and the relative paucity of voluntourism review and discussion sites.

Lastly, international websites emphasised the volunteering part of the experience, while the tourism part tended to reside locally (South African websites). This may be explained via the concept of 'sustainable marketisation' (Bianchi, 2004) and 'colonial humanitarianism' (Clost, 2011): a type of voluntourism where international companies market catching volunteering/humanitarian experiences, and whereby the local tourism sector needs to foster tourism to stimulate the economy. 
Concerning social representation theory, this study is one of the first attempts at exploring the domain of technology mediated tourism experiences through the lens of social representation theory. Although studies applying social representation theory in tourism do exist (Dickinson \& Dickinson, 2006; Dickinson et al., 2009; Moscardo, 2011), this research widens the use of this theory by using the internet as source of data collection. On the other hand, this article contributes to an ever-growing corpus of social representation studies using the internet as a data source (Askitas \& Zimmermann, 2015), by investigating a rising phenomenon in the tourism domain.

From an industry perspective, the above-summarised results allow the authors to draw some recommendations for the use of social media by local (South African) voluntourism players, in order to promote the types of travel they are offering. In particular, local players could leverage the potential of social media and user-generated content to promote their unique voluntourism experiences. Social media discourses related mostly to the 'tourism soul' of the overall experience as well as to some logistical/technical information on visiting the country. However, social media could be used more to present the volunteering part of the experience, by, for example, giving voice to actual volunteers, who can share, and therefore promote, the volunteering activities offered by local organisations.

Acknowledgements: to be added after peer review.

\section{References}

Alexander, Z. (2012). International Volunteer Tourism Experience in South Africa: An Investigation into the Impact on the Tourist. Journal of Hospitality Marketing \& Management, 21(7), 779-799.

Andriotis, K., \& Vaughan, R. D. (2003). Urban Residents' Attitudes toward Tourism Development: The Case of Crete. Journal of Travel Research, 42(2), 172-185.

Askitas, N., \& Zimmermann, K. (2015). The internet as a data source for advancement in social sciences. International Journal of Manpower, 36(1).

Baggio, R., Corigliano, M. A., \& Tallinucci, V. (2007). The Websites of a Tourism Destination: A Network Analysis. In D. M. Sigala, D. L. Mich, \& D. J. Murphy (Eds.), Information and Communication Technologies in Tourism 2007 (pp. 279-288). Springer Vienna. Retrieved from http://link.springer.com/chapter/10.1007/978-3-21169566-1_26

Baggio, R., \& Sainaghi, R. (2011). Complex and chaotic tourism systems: towards a quantitative approach. International Journal of Contemporary Hospitality Management, $23(6), 840-861$.

Bianchi, R. V. (2004). Tourism Restructuring and the Politics of Sustainability: A 
Critical View from the European Periphery (The Canary Islands). Journal of Sustainable Tourism, 12(6), 495-529.

Billig, M. (1996). Arguing and Thinking: A Rhetorical Approach to Social Psychology. Cambridge University Press.

Blackshaw, P. (2006). The consumer-generated surveillance culture. Retrieved from http://www.clickz.com/showPage.html?page=3576076.

Buhalis, D. (2003). ETourism: information technology for strategic tourism management. Harlow, England: Financial Times Prentice Hall.

Buhalis, D., \& Law, R. (2008). Progress in information technology and tourism management: 20 years on and 10 years after the Internet-The state of eTourism research. Tourism Management, 29(4), 609-623.

Butcher, J. (2011). Volunteer Tourism May Not be as Good as It Seems. Tourism Recreation Research, 36(1), 75-76.

Byford, J. (2002). Anchoring and objectifying "neocortical warfare": Representation of a biological metaphor in Serbian conspiracy literature. Papers on Social Representations, 11(3), 1-14.

Callanan, M., \& Thomas, S. (2005). Volunteer tourism: Deconstructing volunteer activities within a dynamic environment. In Niche tourism: Contemporary issues, trends and cases (pp. 183-200). Oxford: Butterworth-Heinemann.

Cape Town Declaration. (2002). Cape Town Conference on Responsible Tourism in Destinations. Cape Town. Retrieved from http://bit.ly/1ub7jAC

Cilibrasi, R. L., \& Vitanyi, P. M. B. (2007). The Google Similarity Distance. IEEE Transactions on Knowledge and Data Engineering, 19(3), 370-383.

Clost, E. (2011). Voluntourism: The Visual Economy of International Volunteer Programs. Thesis (Master, Cultural Studies), Queen's University. Canada. Retrieved from http://hdl.handle.net/1974/6775

Conran, M. (2011). They really love me!: Intimacy in Volunteer Tourism. Annals of Tourism Research, 38(4), 1454-1473.

Corti, I. N., Marola, P. N., \& Castro, M. B. (2010). Social Inclusion and Local Development through European Voluntourism: A Case Study of the Project Realized in a Neighborhood of Morocco. American Journal of Economics and Business Administration, 2(3), 221-231.

Daldeniz, B., \& Hampton, M. (2010). Charity-based voluntourism versus "lifestyle" voluntourism: Evidence from Nicaragua and Malaysia. Kent Business School Working Paper No. 211. University of Kent.

Dickinson, J. E., \& Dickinson, J. A. (2006). Local Transport and Social 
Representations: Challenging the Assumptions for Sustainable Tourism. Journal of Sustainable Tourism, 14(2), 192-208.

Dickinson, J. E., \& Robbins, D. (2008). Representations of tourism transport problems in a rural destination. Tourism Management, 29(6), 1110-1121.

Dickinson, J. E., Robbins, D., \& Fletcher, J. (2009). Representation of transport: A Rural Destination Analysis. Annals of Tourism Research, 36(1), 103-123.

Dykhuis, C. (2010). Youth as voluntourists: A case study of youth volunteering in Guatemala. The Canadian Undergraduate Journal of Development Studies, 7(3), 15-24.

Everingham, P. (2016). Hopeful possibilities in spaces of 'the-not-yet-become': relational encounters in volunteer tourism. Tourism Geographies, 18(5), 520-538.

Escobar, A. (2011). Encountering Development: The Making and Unmaking of the Third World. Princeton University Press.

Farr, R. M. (1996). The roots of modern social psychology, 1872-1954 (Vol. xvii). Malden: Blackwell Publishing.

Fleiss, J. L. (1971). Measuring nominal scale agreement among many raters. Psychological Bulletin, 76(5), 378-382.

Fraser, C. (1994). Attitudes, Social Representations and widespread beliefs. Papers on Social Representations, 3(1). Retrieved from http://www.psych.lse.ac.uk/psr/PSR1994/3_1994Frase1.pdf

Fredline, L., Jago, L., \& Derry, M. (2003). The Development of a Generic Scale to Measure the Social Impacts of Events. Event Management, 8(1), 23-37.

Gretzel, U., Fesenmaier, D., \& O'Leary, J. T. (2006). The transformation of consumer behaviour. Burlington, MA: Elsevier., In D. Buhalis \& C. Costa (Eds.) Tourism Business Frontiers: Consumers, Products and Industry, 9-18.

Gretzel, U., \& Yoo, K. H. (2008). Use and Impact of Online Travel Reviews. In D. P. O'Connor, D. W. Höpken, \& D. U. Gretzel (Eds.), Information and Communication Technologies in Tourism 2008 (pp. 35-46). Springer Vienna. Retrieved from http://link.springer.com/chapter/10.1007/978-3-211-77280-5_4

Guttentag, D. (2011). Volunteer Tourism: As Good as It Seems? Tourism Recreation Research, 36(1), 69-74.

Guttentag, D. A. (2009). The possible negative impacts of volunteer tourism. International Journal of Tourism Research, 11(6), 537-551.

Hammersley, L. A. (2014). Volunteer tourism: building effective relationships of understanding. Journal of Sustainable Tourism, 22(6), 855-873.

Hawkins, D., Lamoureux, K., \& Clemmons, D. (2005). Voluntourism as a catalyst for 
developing the potential of tourism destinations., 7(1), 13-17.

Hecht, B., Teevan, J., Morris, M. R., \& Liebling, D. J. (2012). SearchBuddies: Bringing Search Engines into the Conversation (pp. 138-145). Presented at the ICWSM, 2012.

Holmes, K., Smith, K. A., Lockstone-Binney, L., \& Baum, T. (2010). Developing the Dimensions of Tourism Volunteering. Leisure Sciences, 32(3), 255-269.

Inversini, A., Cantoni, L., \& Buhalis, D. (2009). Destinations' Information Competition and Web Reputation. Information Technology \& Tourism, 11(3), 221-234.

Jang, S. (Shawn). (2004). The Past, Present, and Future Research of Online Information Search. Journal of Travel \& Tourism Marketing, 17(2-3), 41-47.

Jansen, B. J., Booth, D. L., \& Spink, A. (2008). Determining the informational, navigational, and transactional intent of Web queries. Information Processing \& Management, 44(3), 1251-1266.

Jansen, B. J., \& Molina, P. R. (2006). The effectiveness of Web search engines for retrieving relevant ecommerce links. Information Processing \& Management, 42(4),

Kass, J. (2013). Voluntourism. Doctoral dissertation, Brandeis University.

Keese, J. R. (2011). The geography of volunteer tourism: Place matters. Tourism Geographies, 13(2), 257-279.

Kennedy, K., \& Dornan, D. (2009). An Overview: Tourism Non-governmental Organizations and Poverty Reduction in Developing Countries. Asia Pacific Journal of Tourism Research, 14(2), 183-200.

Knollenberg, W., McGehee, N. G., Boley, B. B., \& Clemmons, D. (2014). Motivationbased transformative learning and potential volunteer tourists: facilitating more sustainable outcomes. Journal of Sustainable Tourism, 22(6), 922-941.

Lancia, F. (2012). T-Lab Pathways to Thematic Analysis. T-LAB. Retrieved from http://mytlab.com/

Lyons, K. D., \& Wearing, S. (2012). Reflections on the ambiguous intersections between volunteering and tourism. Leisure Sciences, 34(1), 88-93.

Litvin, S. W., Goldsmith, R. E., \& Pan, B. (2008). Electronic word-of-mouth in hospitality and tourism management. Tourism Management, 29(3), 458-468.

Lupoli, C. A., Morse, W. C., Bailey, C., \& Schelhas, J. (2014). Assessing the impacts of international volunteer tourism in host communities: a new approach to organizing and prioritizing indicators. Journal of Sustainable Tourism, 22(6), 898-921.

Lyons, K. D., \& Wearing, S. (2008). Journeys of Discovery in Volunteer Tourism: International Case Study Perspectives. CABI. 
McGehee, N. G. (2014). Volunteer tourism: evolution, issues and futures. Journal of Sustainable Tourism, 22(6), 847-854.

McGehee, N. G., \& Andereck, K. (2009). Volunteer tourism and the "voluntoured": the case of Tijuana, Mexico. Journal of Sustainable Tourism, 17(1), 39-51.

McGehee, N. G., \& Santos, C. A. (2005). Social change, discourse and volunteer tourism. Annals of Tourism Research, 32(3), 760-779.

McIntosh, A. J., \& Zahra, A. (2007). A Cultural Encounter through Volunteer Tourism: Towards the Ideals of Sustainable Tourism? Journal of Sustainable Tourism, 15(5), 541-556.

Moscardo, G. (2011). Exploring social representations of tourism planning: issues for governance. Journal of Sustainable Tourism, 19(4-5), 423-436.

Moscovici, S. (1961). La Psychanalyse, son image et son public. Paris, France: Presses Universitaires de France - PUF.

Moscovici, S. (1984). The phenomenon of social representations. Social Representations, 3(69).

Moscovici, S. (2000). Social Representations: Studies in Social Psychology. (G. Duveen, Ed.). Polity Press.

Mostafanezhad, M., \& Kontogeorgopoulos, N. (2014). Volunteer tourism policy in Thailand. Journal of Policy Research in Tourism, Leisure and Events, 6(3), 264-267.

Nash, D. (1989). Tourism as a form of imperialism. In Hosts and guests: The anthropology of tourism (Valene L. Smith, pp. 37-52). Philadelphia, PA: University of Pennsilvenia Press.

Nelson, E. D. (2010). A Community Perspective on Volunteer Tourism and Development in South Africa. Miami University. Retrieved from https://etd.ohiolink.edu/ap/10?0::NO:10:P10_ACCESSION_NUM:miami1279848801

Net Market Share. (2018). Market Share Statistics for Internet Technologies. Google Global Market Share on Desktop. Net Market Share. Retrieved from http://tinyurl.com/mgz3zpw

Nor, R., \& Muhlberger, R. (2011). Community Exchange: Designing to Support Empathy and Interaction of Hope. World, 1(1), 137-147.

Pan, B., \& Fesenmaier, D. R. (2006). Online Information Search: Vacation Planning Process. Annals of Tourism Research, 33(3), 809-832.

Parker, I. (1987). "Social representations": Social psychology's (mis)use of sociology. Journal for the Theory of Social Behaviour, 17(4), 447-469.

Pastran, S. H. (2014). Volunteer Tourism: A Postcolonial Approach. USURJ: University of Saskatchewan Undergraduate Research Journal, 1(1). 
Raymond, E. (2011). Volunteer Tourism: Looking Forward. Tourism Recreation Research, 36(1), 77-79.

Riff, D., Lacy, S., \& Fico, F. (2014). Analyzing Media Messages: Using Quantitative Content Analysis in Research. Routledge.

Rosa, A. S. de. (2012). Social Representations in the "Social Arena." Routledge. Sen, A. (1999). Development as Freedom. Oxford University Press.

Sim, J., \& Wright, C. C. (2005). The Kappa Statistic in Reliability Studies: Use, Interpretation, and Sample Size Requirements. Physical Therapy, 85(3), 257-268.

Sin, H. L. (2009). VOLUNTEER TOURISM - "INVOLVE ME AND I WILL LEARN"? Annals of Tourism Research, 36(3), 480-501.

Sin, H. L. (2010). Who are we responsible to? Locals' tales of volunteer tourism. Geoforum, 41(6), 983-992.

Spenceley, A., \& Goodwin, H. (2007). Nature-Based Tourism and Poverty Alleviation: Impacts of Private Sector and Parastatal Enterprises In and Around Kruger National Park, South Africa. Current Issues in Tourism, 10(2-3), 255-277.

Stebbins, R. A. (2009). Would you volunteer? Society, 46(2), 155-159.

Stoddart, H., \& Rogerson, C. M. (2004). Volunteer tourism: The case of Habitat for Humanity South Africa. GeoJournal, 60(3), 311-318.

The National Department of Tourism. (2011). National Minimum Standard for Responsible Tourism (SANS 1162). The National Department of Tourism. Retrieved from http://www.tourism.gov.za/CurrentProjects/ResponsibleTourism/Pages/Information.asp $\mathrm{X}$

Tiessen, R. (2012). Motivations for Learn/Volunteer Abroad Programs: Research with Canadian Youth. Journal of Global Citizenship \& Equity Education, 2(1). Retrieved from http://journals.sfu.ca/jgcee/index.php/jgcee/article/view/57

United Nations Development Programme, (UNDP). (2013). The Rise of the South: Human Progress in a Diverse World. (Human Development Reports). Retrieved from http://hdr.undp.org/en/2013-report

Van Zyl, I., Inversini, A., \& Rega, I. (2015). The representation of voluntourism in search engines: The case of South Africa. Development Southern Africa, O(0), 1-17.

Wagner, W., Duveen, G., Farr, R., Jovchelovitch, S., Lorenzi-Cioldi, F., Marková, I., \& Rose, D. (1999). Theory and Method of Social Representations. Asian Journal of Social Psychology, 2(1), 95-125.

Wang, Y. (Alex), \& Pfister, R. E. (2008). Residents' Attitudes Toward Tourism and 
Perceived Personal Benefits in a Rural Community. Journal of Travel Research, 47(1), 84-93.

Wearing, S. (2001). Volunteer Tourism: Experiences That Make a Difference. CABI.

Wöber, K. (2006). Domain Specific Search Engines. In Destination Recommendation Systems: Behavioural Foundations and Applications. CABI.

Xiang, Z., \& Gretzel, U. (2010). Role of social media in online travel information search. Tourism Management, 31(2), 179-188.

Xiang, Z., Wöber, K., \& Fesenmaier, D. R. (2008). Representation of the Online Tourism Domain in Search Engines. Journal of Travel Research, 47(2), 137-150.

Yuksel, F., Bramwell, B., \& Yuksel, A. (1999). Stakeholder interviews and tourism planning at Pamukkale, Turkey. Tourism Management, 20(3), 351-360. 
[TABLE 1]

\begin{tabular}{|l|l|}
\hline Variable & Values \\
\hline TYPE (website type) & TRAD (traditional) \\
& SOC (social) \\
\hline LOC (location) & INT (international) \\
& SA (South Africa) \\
\hline KEY (keyword) & GEN (general) \\
& ACT (activities) \\
& GEO (geographical) \\
\hline
\end{tabular}

Table 1: Variables for corpus classification

[TABLE 2]

Clusters

\begin{tabular}{|c|c|c|c|}
\hline \multirow{3}{*}{$\begin{array}{l}\text { Cluster\# } \\
\text { Weight } \\
\text { Themes }\end{array}$} & 1 & 2 & 3 \\
\hline & $37.6 \%$ & $35.9 \%$ & $26.5 \%$ \\
\hline & $\begin{array}{l}\text { The volunteering } \\
\text { experience }\end{array}$ & $\begin{array}{l}\text { A tourism experience: what } \\
\text { to see and what to do }\end{array}$ & $\begin{array}{l}\text { A holistic view of } \\
\text { voluntourism }\end{array}$ \\
\hline Lemmas & $\begin{array}{l}\text { volunteer, work, } \\
\text { child, help, need, } \\
\text { week, teach, } \\
\text { project, } \\
\text { experience, care, } \\
\text { program, job, } \\
\text { family, school }\end{array}$ & $\begin{array}{l}\text { Cape, hotel, town, contact, } \\
\text { city, Kimberly, tour, review, } \\
\text { description, region, museum, } \\
\text { tel, location, bay, park, } \\
\text { Pietermaritzburg, website, } \\
\text { email, edit, lodge, safari, } \\
\text { mountain, Drakensberg, } \\
\text { route, Bloemfontein, house, } \\
\text { accommodation, natal, road, } \\
\text { game }\end{array}$ & $\begin{array}{l}\text { Tourism, development, } \\
\text { Gauteng, investments, } \\
\text { sustainable, corporate, } \\
\text { leisure, travel, } \\
\text { community, practise, } \\
\text { responsible, } \\
\text { international, } \\
\text { education, impact, } \\
\text { market, research, } \\
\text { social, environment }\end{array}$ \\
\hline
\end{tabular}

Table 2: Clusters description

[TABLE 3] 


\begin{tabular}{|l|l|l|l|}
\hline $\begin{array}{l}\text { LEMMAS \& } \\
\text { VARIABLES }\end{array}$ & $\mathbf{C H I}^{2}$ & $\begin{array}{l}\text { E.C. IN } \\
\text { CLUSTER }\end{array}$ & $\begin{array}{l}\text { E.C. IN } \\
\text { TOTAL }\end{array}$ \\
\hline volunteer & $1,955,479$ & 4408 & 7152 \\
\hline work & $1,154,741$ & 1515 & 2086 \\
\hline child & 796,151 & 841 & 1072 \\
\hline help & 701,423 & 753 & 966 \\
\hline need & 667,899 & 668 & 835 \\
\hline week & 584,28 & 623 & 797 \\
\hline teach & 547,966 & 424 & 479 \\
\hline project & 519,769 & 1548 & 2665 \\
\hline experience & 496,487 & 1095 & 1752 \\
\hline care & 414,521 & 369 & 441 \\
\hline program & 363,94 & 999 & 1686 \\
\hline job & 353,437 & 410 & 540 \\
\hline family & 342,793 & 404 & 535 \\
\hline school & 310,249 & 656 & 1037 \\
\hline & & &
\end{tabular}

Table 3: Lemmas in cluster 1 (The volunteering experience)

[TABLE 4]

\begin{tabular}{|l|l|l|l|}
\hline $\begin{array}{l}\text { LEMMAS \& } \\
\text { VARIABLES }\end{array}$ & CHI $^{\mathbf{2}}$ & $\begin{array}{l}\text { E.C. IN } \\
\text { CLUSTER }\end{array}$ & E.C. IN TOTAL \\
\hline cape & 1579,12 & 1724 & 2274 \\
\hline KEY_GEO & 1543,09 & 2576 & 3910 \\
\hline Hotel & $1,154,722$ & 721 & 757 \\
\hline Town & 931,927 & 1317 & 1893 \\
\hline contact & 882,239 & 874 & 1109 \\
\hline _LOC_SA & 859,723 & 2240 & 3824 \\
\hline City & 842,623 & 674 & 787 \\
\hline _TYPE_SOC & 836,109 & 1208 & 1748 \\
\hline kimberley & 835,818 & 495 & 507 \\
\hline tour & 822,98 & 935 & 1248 \\
\hline review & 783,296 & 869 & 1150 \\
\hline description & 685,296 & 426 & 446 \\
\hline region & 649,647 & 475 & 534 \\
\hline Museum & 613,235 & 376 & 391 \\
\hline Tel & 606,456 & 356 & 363 \\
\hline location & 537,129 & 408 & 466 \\
\hline bay & 535,761 & 379 & 420 \\
\hline park & 522,274 & 516 & 654 \\
\hline
\end{tabular}




\begin{tabular}{|l|l|l|l|}
\hline pietermaritzburg & 477,848 & 316 & 340 \\
\hline website & 472,494 & 414 & 501 \\
\hline email & 462,181 & 378 & 445 \\
\hline edit & 425,068 & 250 & 255 \\
\hline lodge & 421,97 & 354 & 421 \\
\hline safari & 353,605 & 301 & 360 \\
\hline Mountain & 351,356 & 222 & 234 \\
\hline drakensberg & 338,525 & 209 & 218 \\
\hline route & 330,509 & 223 & 242 \\
\hline bloemfontein & 329,563 & 226 & 247 \\
\hline house & 314,036 & 372 & 503 \\
\hline accommodation & 313,246 & 413 & 579 \\
\hline natal & 308,95 & 247 & 288 \\
\hline road & 301,753 & 203 & 220 \\
\hline game & 301,647 & 344 & 459 \\
\hline
\end{tabular}

Table 4: Lemmas in cluster 2 (A tourism experience: what to see and what to do)

[TABLE 5]

\begin{tabular}{|l|l|l|l|}
\hline $\begin{array}{l}\text { LEMMAS \& } \\
\text { VARIABLES }\end{array}$ & CHI $^{\mathbf{2}}$ & $\begin{array}{l}\text { E.C. IN } \\
\text { CLUSTER }\end{array}$ & E.C. IN TOTAL \\
\hline tourism & $4,893,951$ & 2405 & 2836 \\
\hline development & $3,111,237$ & 1525 & 1790 \\
\hline gauteng & $1,679,291$ & 807 & 935 \\
\hline Investments & $1,272,402$ & 469 & 469 \\
\hline sustainable & 847,908 & 347 & 368 \\
\hline corporate & 647,612 & 262 & 276 \\
\hline leisure & 571,855 & 267 & 304 \\
\hline travel & 562,949 & 956 & 1866 \\
\hline community & 523,835 & 1029 & 2099 \\
\hline practise & 519,387 & 213 & 226 \\
\hline responsible & 403,133 & 306 & 441 \\
\hline international & 402,484 & 493 & 861 \\
\hline education & 381,104 & 504 & 904 \\
\hline impact & 371,433 & 331 & 511 \\
\hline market & 371,321 & 336 & 522 \\
\hline research & 332,6 & 330 & 532 \\
\hline Social & 328,006 & 289 & 444 \\
\hline Environmental & 311,202 & 209 & 285 \\
\hline
\end{tabular}

Table 5: Lemmas in cluster 4 (A holistic view of voluntourism) 
[FIGURE 1]

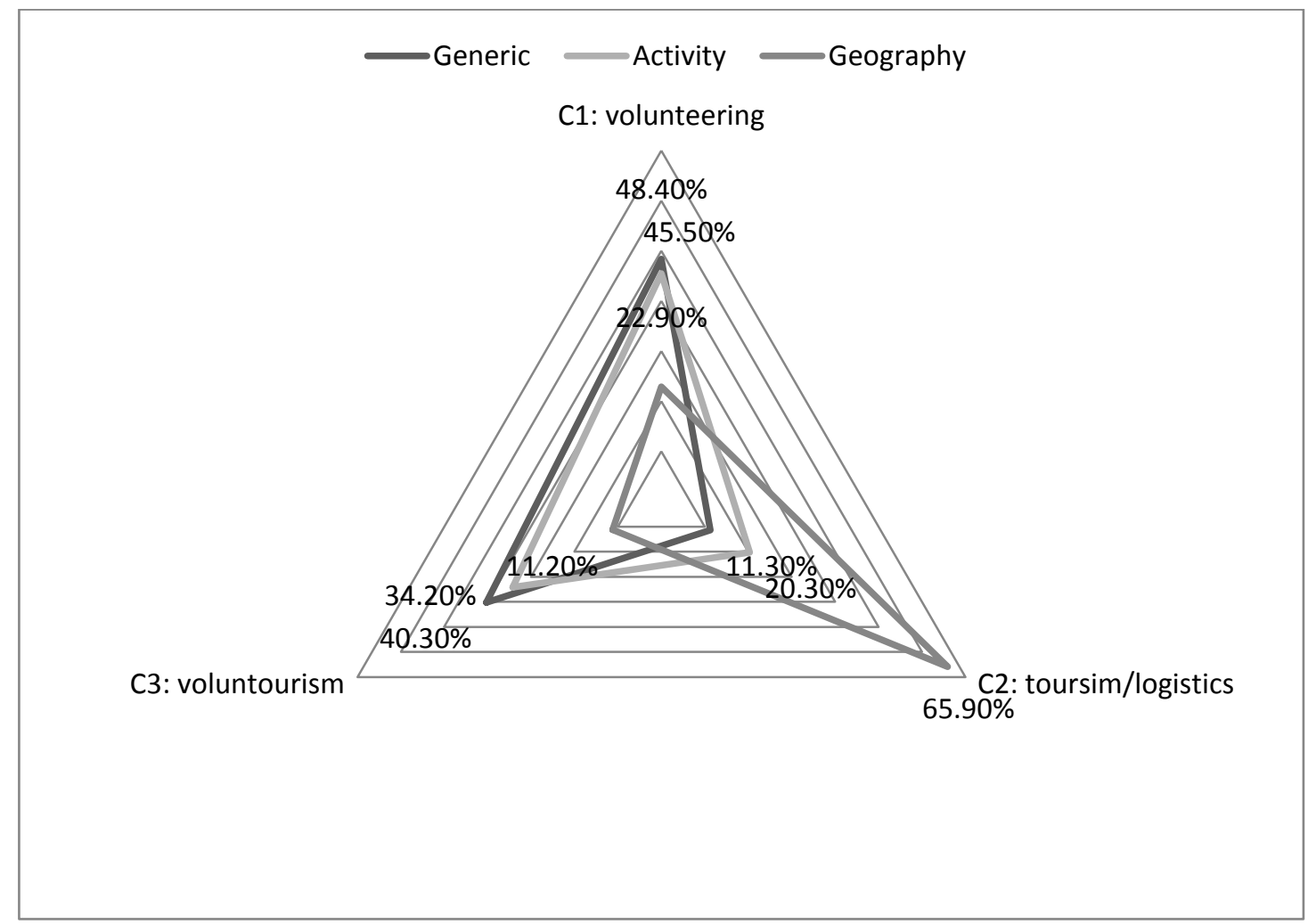

Figure 1: the distribution of the variable "keyword" within the clusters

[FIGURE 2]

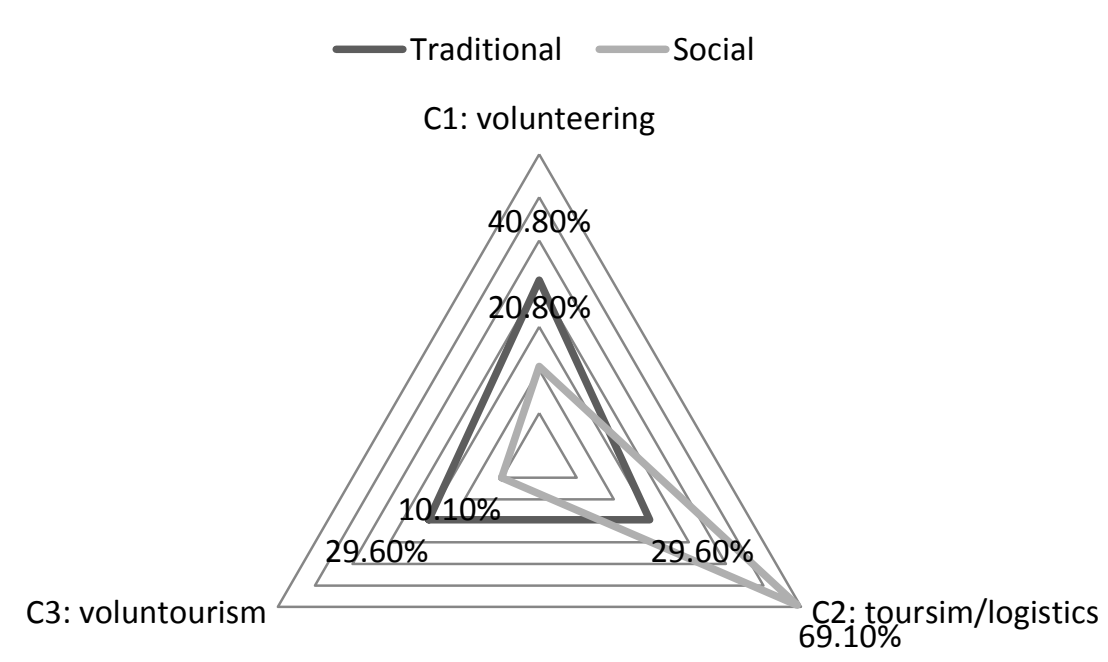


Figure 2: the distribution of the variable "typology" within the clusters

[FIGURE 3]

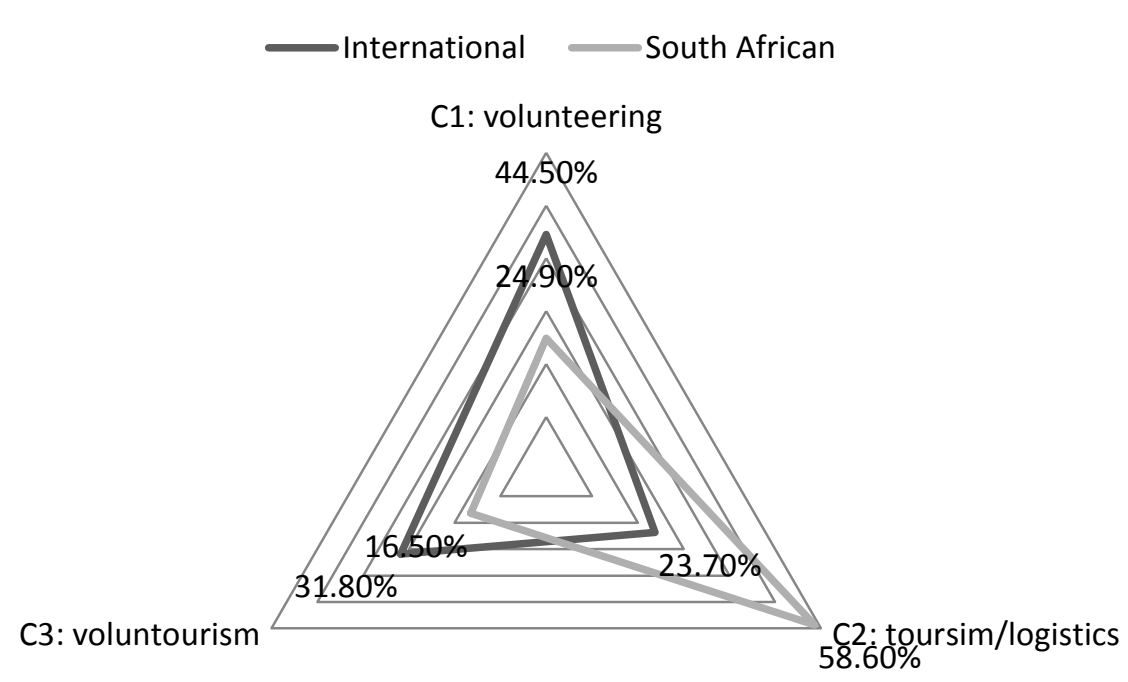

Figure 3: the distribution of the variable "location" within the clusters 